\title{
KEEFEKTIFAN MODEL PEMBELAJARAN KOOPERATIF TIPE PICTURE AND PICTURE DAN THINK-PAIR-SHARE DALAM PEMBELAJARAN MENULIS DESKRIPSI
}

\author{
Febe Fenny Irawati Wanggai ${ }^{\mathbf{1}}$, Maksimilianus Doi ${ }^{2}$ \\ ${ }^{1,2}$ Universitas Flores, Fakultas Bahasa dan Sastra \\ email korespondensi: fheiralexon@gmail.com
}

\begin{abstract}
Abstrak
Penelitian ini bertujuan untuk mengetahui (1) perbedaan yang signifikan antara model kooperatif tipe picture and picture, think-pair-share, dan model tradisional dalam pembelajaran menulis deskripsi peserta didik kelas $\mathrm{X}$ SMAK Frateran Ndao Ende, (2) manakah yang paling efektif antara model kooperatif tipe picture and picture, think-pair-share, dan model tradisional dalam pembelajaran menulis deskripsi peserta didik kelas X SMAK Frateran Ndao Ende. Penelitian ini menggunakan metode eksperimen semu dengan desain Randomized Control-Group Pretest-Posttest Design. 90 siswa dari 30 siswa setiap kelasnya dijadikan sampel penelitian dari 3 kelas utuh dengan teknik total sampling. Pengumpulan data penelitian melalui metode non-tes berupa penugasan menulis deskripsi. Teknik analisis data menggunakan Anava satu jalan yang dilanjutkan dengan uji Scheffe. Hasil penelitian menunjukkan bahwa (1) terdapat perbedaan penggunaan model kooperatif tipe picture and picture, think-pair-share, dan model konvensional dalam pembelajaran menulis deskripsi dengan nilai $\mathrm{F}=140,578$ dan sig. $(p)<0,05$, (2) model kooperatif tipe think-pair-share paling efektif dalam pembelajaran menulis deskripsi.
\end{abstract}

Kata Kunci: keefektifan, picture and picture, think-pair-share, menulis deskripsi

\begin{abstract}
The current study aimed at investigating (1) a significant difference of cooperative models of picture and picture, think-pair-share, and conventional model, (2) the most significant effectiveness of cooperative models of picture and picture, think-pair-share, and conventional model in learning process of descriptive writing at grade X of the students of SMAK Frateran Ndao Ende. This study belonged to quasi-experimental study with randomized control-group pretest-posttest design. 90 students with 30 students in each class were employed as samples using total sampling technique with three intact classes. The data were a non-test method in the form of a descriptive writing assignment. The data were analyzed using oneway ANOVA continued by Scheffe test. The upshots of the study denote that (1) there is a significant difference of cooperative models of picture and picture, think-pair-share, and conventional model in the learning process of descriptive writing with $F=140.578$, and a significant value of $p<0.05$, (2) cooperative model of think-pair-share is the most effective type in the learning process of descriptive writing.
\end{abstract}

Keywords: effectiveness, picture and picture, think-pair-share, descriptive writing 


\section{PENDAHULUAN}

Salah satu kegiatan menulis adalah menulis karangan deskripsi. Karangan deskripsi adalah karangan yang menggambarkan suatu hal atau benda secara jelas sehingga pembaca bisa merasakan, mengalami, atau melihat sendiri apa yang sedang dibahas di dalam tulisan. Dalam karangan deskripsi, penulis menggambarkan hasil pengamatan, perasaan, dan pengalamannya kepada pembaca (Tompkins, 1994:111: Junus, 2002:61; Dalman, 2014:94). Sasaran lain yang ingin dicapai oleh seorang penulis adalah menciptakan imajinasi pada pembaca seolah-olah mereka melihat sendiri suatu objek secara keseluruhan (Keraf, 1981:93; Roffi'udin: 2001, 117; Saddhono \& Slamet, 2014:159).

Berdasarkan pengamatan awal, pembelajaran menulis menitikberatkan pada hasil tulisan. Kurangnya model pembelajaran menulis menyebabkan siswa tidak maksimal merangkai gagasannya dalam tulisan. Guru memerlukan model pembelajaran yang kreatif dan inovatif. Model pembelajaran banyak ditawarkan oleh para ahli untuk meningkatkan keterampilan menulis siswa. Salah satu model pembelajaran adalah model pembelajaran kooperatif dimana siswa dalam kelompok bekerja sama menyelesaikan tugas untuk membangun pengetahuan serta pemahaman yang relevan dengan materi pelajaran. Slavin (2010:4; Jacobsen, dkk, 2009:95) menguraikan pembelajaran kooperatif merujuk pada berbagai macam metode pengajaran di mana siswa bekerja sama dalam kelompok. Dalam proses pembelajaran, siswa didorong untuk bekerja sama pada suatu tugas dan harus menyelesaikan tugas yang diberikan guru (Abidin, 2014:241-242; Hartoto, 2016).

Tipe model pembelajaran kooperatif meliputi jigsaw, picture and picture, CIRC, think-talk-write (TTW), think-pair-share (TPS), concept sentence, time token, take and give, STAD, dan lain sebagainya. Pada penelitian ini, peneliti akan fokus pada dua model pembelajaran kooperatif, yakni tipe picture and picture dan think-pairshare (TPS). Menurut Nurhadi (2003:60), tipe picture and picture adalah model pembelajaran dimana guru menunjukkan gambar-gambar yang berkaitan dengan materi yang disajikan dan siswa dapat mengurutkan dasar pemikiran urutan gambar 
tersebut menjadi beberapa kalimat untuk dikembangkan menjadi paragraf. Tipe thinkpair-share, menurut Slavin (2010:257), adalah model pembelajaran yang dirancang untuk berpikir tentang materi yang disampaikan oleh guru dan setiap kelompok melakukan diskusi bersama dan mengemukakannya ke dalam sebuah tulisan.

Dari hasil pengamatan yang dilakukan di SMAK Frateran Ndao-Ende, guru belum pernah menggunakan model pembelajaran kooperatif tipe picture and picture dan think-pair-share dalam pembelajaran menulis, terutama karangan deskripsi. Guru mengajar dengan menggunakan kemampuan verbal. Dalam praktiknya, siswa terpaku pada buku pelajaran. Kemampuan dan motivasi menulis deskripsi sangat rendah. Dengan demikian, peneliti mencoba menerapkan tipe picture and picture dan thinkpair-share dalam menulis deskripsi.

\section{METODE PENELITIAN}

Penelitian ini menggunakan pendekatan kuantitatif karena penelitian ini bertujuan membuktikan teori terhadap fakta-fakta yang ada di lapangan. Adapun tujuan penelitian ini adalah membuktikan keefektifan model kooperatif tipe picture and picture dan think-pair-share dalam pembelajaran menulis deskripsi. Desain penelitian yang digunakan dalam penelitian ini adalah desain eksperimen semu dengan Randomized Control-Group Pretest-Posttest Design. Sementara itu, penelitian ini dilakukan pada siswa Kelas X SMAK Frateran Ndao yang terdiri dari 3 kelas dan setiap kelasnya berjumlah 30 siswa. Jadi, populasinya adalah 90 siswa dan keseluruhannya dijadikan sampel (total sampling) dengan tiga kelas utuh (intact class) yang secara acak (random sampling) dab dipilih 2 kelas eksperimen dan satu kelas kontrol. Kelompok eksperimen dan kelompok kontrol diberikan tes awal (pretest) keterampilan menulis, kemudian dilakukan uji perbedaan kemampuan menulis antara ketiganya untuk memperoleh kondisi awal yang sama. Pada akhir perlakuan dilihat perbedaan pencapaian pretest dan posttest kelompok eksperimen dan perbedaan pretest dan posttest kelompok kontrol. Teknik pengumpulan data dilakukan berupa penugasan menulis karangan deskripsi. Aspek yang diukur adalah menulis karangan deskripsi siswa yang berkaitan dengan pembelajaran menulis 
karangan deskripsi dengan menggunakan model kooperatif picture and picture, thinkpair-share, dan konvensional. Oleh karena itu, data yang akan diteliti berupa hasil menulis karangan. Penugasan menulis karangan deskripsi dibuat berlandaskan teori, berpedoman pada kurikulum yang digunakan dan disesuaikan dengan bahan pengajaran. Kurikulum yang digunakan di SMAK Frateran Ndao kelas X adalah kurikulum 2013. Instrumen pengumpulan data dilakukan dengan menggunakan instrumen lembar penilaian menulis karangan deskripsi. Kriteria penilaian berisi faktor-faktor yang berkaitan dengan penilaian karangan berdasarkan pada penilaian karangan seperti yang diungkapkan oleh Jacobs, dkk. (1981, dalam ARSLAN, 2014.)

Table 1. Rubrik Penilaian Menulis

\begin{tabular}{|c|c|c|c|c|}
\hline AREA & & CRITERIA & SCO & \\
\hline \multirow{4}{*}{ Content } & Excellent to very good & $\begin{array}{l}\text { Excellent toverry good treatment of the subject or topic, topic narrow } \\
\text { enough, considerable variety of ideas, independent and thorough } \\
\text { interpretation of the topic, content relevant to the topic, accurate detalis, } \\
\text { original ideas, clear purpose for writing }\end{array}$ & $24-30$ & \\
\hline & Good to average & $\begin{array}{l}\text { Adequate treatment of topics; some variety of ideas or argument; some } \\
\text { independence of interpretation of the topic; most content relevant to the } \\
\text { topic; reasonably accurate detail. }\end{array}$ & $18-23$ & \\
\hline & Fair to poor & $\begin{array}{l}\text { Treatmentof the topic is hardly adequate; little variety of ideas; some } \\
\text { irrelevant content; lacking detail }\end{array}$ & $10-17$ & 30 \\
\hline & Very poor & $\begin{array}{l}\text { Inadequate treatment of the topic; very broad topic; no purpose for } \\
\text { writing; no variety of ideas or argument; content irrelevant' almost no } \\
\text { useful detail }\end{array}$ & $6-9$ & \\
\hline \multirow{7}{*}{ Organization } & $\begin{array}{l}\text { Inadequate } \\
\text { (Not enough for assessment) }\end{array}$ & Fails to adress the task with any effectiveness & $0-5$ & \\
\hline & Excellent to very good & $\begin{array}{l}\text { Fluent expression, ideas clearly stated and supported, appropiately } \\
\text { organized paragraph(s) or sections; effective introduction, strong } \\
\text { supportt and effective conclusion; logically sequenced (coherence), } \\
\text { connectives appropiately used (cohesion) }\end{array}$ & $17-20$ & \\
\hline & Good to average & $\begin{array}{l}\text { Uneven expression, but main ideas statnd out; paragraphing or section } \\
\text { organization evident; logically sequenced (coherence), connectives used } \\
\text { (cohesion) }\end{array}$ & $12-16$ & 20 \\
\hline & Fair to poor & $\begin{array}{l}\text { Very uneven expression, ideas difficult to follow, organization does not } \\
\text { help reader; logical sequence difficult to follow (coherence); } \\
\text { connectives largely absent (cohesion) }\end{array}$ & $8-11$ & \\
\hline & Very poor & $\begin{array}{l}\text { Lacks fluent expression, ideas very difficult to follow; little sense of } \\
\text { organization; ineffective introduction, weak support and poor } \\
\text { conclusion, no sense of logical sequence (coherence), connectives not } \\
\text { used (cohesion) }\end{array}$ & $5-7$ & \\
\hline & $\begin{array}{l}\text { Inadequate } \\
\text { (Not enough for assessment) }\end{array}$ & Fails to adress this aspect of the task with any effectiveness & $0-4$ & \\
\hline & Excellent to Very Good & $\begin{array}{l}\text { Confident handling of appropiate structures, sentences well-built and } \\
\text { structures strong and varied, hardly any errors of agreement, tense, } \\
\text { number, word order, article, pronouns, prepositions, meaning never } \\
\text { obscured. }\end{array}$ & $17-20$ & \\
\hline \multirow[b]{2}{*}{ Language use } & Good to Average & $\begin{array}{l}\text { Accpetable grammar, but problems with more complex structures, } \\
\text { mostly appropiate structures, some errors on agreement, tense, number, } \\
\text { word order, article }\end{array}$ & $12-16$ & \\
\hline & Fair to Poor & $\begin{array}{l}\text { Insufficient range of structures with control only shown in simple } \\
\text { construction, frequent errors on aggrement, tense, number, word order, } \\
\text { articles, pronouns, preposition, meaning sometimes obscured }\end{array}$ & $8-11$ & 20 \\
\hline
\end{tabular}




$\begin{array}{ll} & \text { Very Poor } \\ & \text { Inadequate } \\ & \text { Excellent to Very Good } \\ & \text { Good to Average } \\ & \text { Fair to Poor } \\ \text { Vocabulary/ } & \text { Very Poor } \\ \text { Word choice } & \text { Inadequate } \\ & \text { Excellent to Very Good } \\ & \text { Good to Average } \\ & \text { Fair to Poor } \\ & \text { Very Poor }\end{array}$

Major problems w ith structures-even simple ones, sentences and structures poor, incomplete or awkward, frequent errors of negation, agreement, tense, nmber, word order,/function, articles, pronouns, prepositions, meaning often obscured.

Fails to adress this aspect of the task with any effectiveness
Wide range of vocabulary, occasional mistakes in word/idiom choice and usage; register not always appropiate

Adequate range of vocabulary, occasional mistakes in word/idiom choice and usage; register not always appropiate.

Limited range of vocabulary, uncomfortably frequent word/idiom choice and usage, register not always appropiate

No range of vocabulary, uncomfortable frequent word/idiom choice and usage, no apparent sense of register

Fails to adress this aspect of the task with any effectiveness.

Demonstrate full command of writing coventions such as spelling, punctuation, capitalization, and layout

Occasional errors in spelling, punctuation, capitalization, and layout

Frequent errors in spelling, punctuation, capitalization, and layout

Very poor mastery of conventions; full of errors of spelling, punctuation, and capitalization, alyout is distracting. Fails to adress this aspect of the task with any effectiveness.

Total

Teknik analisis data yang digunakan dalam penelitian ini adalah teknik analisis varian (Anava) satu jalur yang kemudian dilanjutkan dengan uji scheffe. Dalam melakukan teknik analisis statistik Anava, normalitas skor menulis karangan deskripsi yang berupa data pretest dilakukan dengan menggunakan uji Lilliefors Significance Correlation dari Kolmogorov Smirnov dengan taraf signifikansi $(\alpha=$ 0,05) dengan SPSS versi 20. Jika nilai sig atau signifikansi atau probabilitas kurang dari 0,05, data tidak berdistribusi normal. Sebaliknya, jika nilai sig atau signifikansi atau probabilitas lebih dari 0,05, data berdistribusi normal. Selain itu, untuk menguji apakah antara ketiga kelompok tersebut homogen atau tidak dilakukan dengan teknik analisis varian satu jalan (one way anova) dengan melihat lavene test. Penerimaan atau penolakan uji homogenitas didasarkan pada nilai sig $<0,05$, ketiga varian populasi tidak homogen; dan jika nilai sig > 0,05, ketiga varian populasi adalah homogen. Tes statistik untuk menguji homogenitas adalah uji F, yaitu dengan membandingkan varians terbesar dengan varian terkecil. Hasil dari perhitungan kemudian dikonsultasikan dengan tabel nilai F. Jika F0<F1 maka dapat dinyatakan bahwa kedua kelompok sampel tersebut variannya tidak berbeda secara signifikan atau homogen. $\mathrm{F}_{0}$ adalah nilai $\mathrm{F}$ yang diperoleh dari hasil perhitungan dan $\mathrm{F}_{1}$ adalah nilai $\mathrm{F}$ yang diperoleh dari tabel. Taraf signifikansi yang dikehendaki adalah 5\% dengan derajat kebebasan $(\mathrm{db})=(\mathrm{n} 1-1)$ untuk pembilang dan $(\mathrm{n} 2-1)$ untuk penyebut. 
Seluruh proses perhitungan selengkapnya dibantu dengan komputer program SPSS versi 20. Teknik yang digunakan dalam analisis data adalah anava satu jalur atau one way analysis of variance (Anova). Dengan ketentuan jika Fhitung lebih kecil dari $\mathrm{F}_{\text {tabel, }}$ maka Ho diterima, artinya tidak signifikan. Jika $F_{\text {hitung }}$ lebih besar dari $F_{\text {tabel, }}$ maka Ho ditolak artinya signifikan. Untuk mengetahui urutan keefektifan antara model pembelajaran kooperatif tipe picture and picture, think-pair-share, dan model konvensional dalam pembelajaran menulis deskripsi dilakukan uji Scheffe.

\section{HASIL DAN PEMBAHASAN}

\section{Deskripsi Kemampuan Awal}

Data Pretest Kelompok Eksperimen 1 (Tipe Picture and Picture)

Pada kelas X MIPA 2 SMAK Frateran Ndao Ende, model pembelajaran koperatif yang digunakan adalah tipe picture and picture dengan jumlah perlakuan sebanyak 6 kali pertemuan. Dari hasi pretest diperoleh mean sebesar 45,4615; standar devias 7,37689; variansi 54,418; nilai maksimum 63; dan nilai minimum 32. Berdasarkan distribusi frekuensi skor hasil pretest diketahui bahwa kelompok eksperimen 1 yang memperoleh skor 59-63 sebanyak 1 (3,3\%), skor 54-58 sebanyak 4 (13,3\%), skor 4953 sebanyak 5 (16,6\%), skor 44-48 sebanyak 6 (20\%), skor 39-43 sebanyak 11 $(36,6 \%)$, dan skor 34-38 sebanyak 3 (9,9\%). Dengan demikian, frekuensi skor terbanyak terdapat pada interval 39-43 yang berjumlah 11 peserta didik $(36,6 \%)$. Deskripsi statistik antara penilai 1 dan penilai 2 pada kelompok eksperimen 1 tampak bahwa rata-rata (mean) penilai 1 adalah 45,47, sedangkan penilai 2 menunjukkan skor rata-rata (mean) sebesar 45,63.

Data Pretest Kelompok Eksperimen 2 (Tipe Think-Pair-Share)

Model pembelajaran yang diterapkan pada kelompok eksperimen 2 pada kelas $\mathrm{X}$ MIPA 3 adalah model pembelajaran kooperatif tipe think-pair-share. Berdasarkan hasil pretest diketahui bahwa rata-rata menulis deskripsi peserta didik (mean) sebesar 47,43; standar deviasi 8,605; variansi 74,047; nilai maksimum 61; dan nilai minimum 28. Frekuensi skor pretest kelompok eksperimen 2 diketahui bahwa skor 58-63 sebanyak 4 (13,3\%); skor 52-57 sebanyak 5 (16,7\%); skor 46-51 sebanyak 14 
(46,6\%); skor 40-45 sebanyak 2 (6,6\%); skor 34-39 sebanyak 2 (6,6\%); dan skor 2833 sebanyak 3 (9,9\%). Juga, frekuensi terbanyak terjadi pada interval 46-51 berjumlah 14 peserta didik (46,6\%). Sementara itu, deskripsi statistik antara penilai 1 dan penilai 2 pada kelompok eksperimen 2 bahwa rata-rata (mean) penilai 1 adalah 47,60, sedangkan penilai 2 menunjukkan skor rata-rata (mean) sebesar 46,87.

\section{Data Pretest Kelompok Kontrol}

Peserta kelompok kontrol adalah kelas X MIPA 1. Pembelajaran dilaksanakan menggunakan model konvensional yang biasa dilakukan oleh guru. Dari hasil pretest yang dilakukan diketahui bahwa skor rata-rata menulis deskripsi peserta didik (mean) sebesar 49,67; standar deviasi 8,023; variansi 64,368; nilai maksimum 62; dan nilai minimum 27 dan frekuensi skor 59-66 sebanyak 4 (13,3\%), 51-58 sebanyak 13 (43,4\%), 43-50 sebanyak 8 (26,6\%), 35-42 sebanyak 3 (10\%), dan 27-34 sebanyak 2 $(6,6 \%)$. Frekuensi terbanyak terdapat pada interval 51-58 berjumlah 13 peserta didik $(43,4 \%)$. Selain itu, deskripsi statistik antara penilai 1 dan penilai 2 pada kelompok kontrol adalah bahwa rata-rata (mean) penilai 1 adalah 49,20, sedangkan penilai 2 menunjukkan skor rata-rata (mean) sebesar 49,73.

\section{Deskripsi Kemampuan Akhir}

\section{Data Posttest Kelompok Eksperimen 1 (Tipe Picture and Picture)}

Hasil posttest menulis kelompok eksperimen 1 dengan tipe picture and picture diketahui bahwa skor rata-rata (mean) sebesar 77,1538; standar deviasi 5,47498; variansi sebesar 29,975; nilai maksimum 84; dan nilai minimum 63. Persentasi hasil posttest adalah skor 81-86 sebanyak 10 (33,3\%), 75-80 sebanyak 8 (26,6\%), 69-74 sebanyak $10(33,4 \%)$, dan 63-68 sebanyak 2 (6,6\%). Frekuensi terbanyak terdapat pada interval 69-74 dan interval 81-86 yang masing-masing berjumlah 10 peserta didik (33,4\%). Di samping itu, deskripsi statistik antara penilai 1 dan penilai 2 pada kelompok eksperimen 1 adalah bahwa rata-rata (mean) penilai 1 adalah 76,90, sedangkan penilai 2 menunjukkan skor rata-rata (mean) sebesar 76,73. Korelasi antarrater adalah 0,906 dan antara penilai 1 dan penilai 2 mempunyai korelasi dalam 
menilai kemampuan menulis deskripsi peserta didik. Jadi, pemahaman kedua penilai terhadap indikator penilaian menulis deskripsi adalah sama.

Data Posttest Kelompok Eksperimen 2 (tipe Think-Pair-Share)

Besarnya skor menulis karangan deskripsi kelompok eksperimen 2 yang diperoleh dari hasil posttest dapat diketahui bahwa skor rata-rata (mean) menulis deskripsi peserta didik sebesar 80,63; standar deviasi 4,767; variansi sebesar 22,723; nilai maksimum 94; dan nilai minimum 74. Hasil posttest kelompok eksperimen 2 yang memperoleh skor 94-98 sebanyak 1 (3,3\%); skor 89-93 sebanyak 2 (6,6\%); skor 84-88 sebanyak 1 (3,3\%); skor 79-83 sebanyak 13 (43,4\%), dan skor 74-78 sebanyak $13(43,4 \%)$. Frekuensi skor terbanyak terdapat pada interval 74-78 dan interval 79-83 yang masing-masing berjumlah 13 peserta didik (43,4\%). Deskripsi statistik antara penilai 1 dan penilai 2 pada kelompok eksperimen 2 adalah bahwa rata-rata (mean) penilai 1 adalah 80,47, sedangkan penilai 2 menunjukkan skor rata-rata (mean) sebesar 80,50. Korelasi antarrater adalah 0,921 dan dapat disimpulkan bahwa antara penilai 1 dan penilai 2 mempunyai korelasi dalam menilai kemampuan menulis deskripsi sehingga pemahaman kedua penilai terhadap indikator penilaian menulis deskripsi adalah sama.

\section{Data Posttest Kelompok Kontrol}

Besarnya skor menulis karangan deskripsi kelompok kontrol adalah skor rata-rata (mean) menulis deskripsi sebesar 60,27; standar deviasi 4,705; variansi sebesar 22,133; nilai maksimum 70; dan nilai minimum 47. Hasil posttest kelompok kontrol adalah skor 67-70 sebanyak 2 (6,6\%), 63- 66 sebanyak 7 (23,3\%), 59-62 sebanyak 12 (40,1\%), 55-58 sebanyak 7 (23,3\%), 51-54 sebanyak 1 (3,3\%), dan 47-50 sebanyak 1 $(3,3 \%)$. Frekuensi skor terbanyak terdapat ada pada interval 59-62 yang berjumlah 12 peserta didik (40,1\%). Sementara itu, hasil deskripsi statistik antara penilai 1 dan penilai 2 menunjukkan bahwa rata-rata (mean) pada penilai 1 adalah 60,10, sedangkan penilai 2 menunjukkan mean sebesar 60,00. Korelasi antarrater adalah 0,866 dan dapat disimpulkan bahwa korelasi antara penilai 1 dan penilai 2 adalah sama. 


\section{Uji Persyaratan Analisis}

\section{Uji Normalitas}

Uji normalitas dilakukan dengan uji Kolmogorov-Smirnov. Kriteria pengujian adalah Ho ditolak apabila nilai Asymp. Sig. (2-tailed)>0,05. Sebaliknya, Ho diterima apabila nilai Asymp. Sig. $(2$-tailed $)<0,05$. Hasil uji normalitas skor menulis deskripsi dengan Kolmogorov-Smirnov menggunakan program SPSS versi 20.00.

Tabel 2. Hasil Uji Normalitas

\begin{tabular}{lrl}
\hline Kelompok & $\begin{array}{c}\text { Asynp. Sig.(2- } \\
\text { tailed) }\end{array}$ & Keterangan \\
\hline Pretest kelompok eksperimen 1 & $0 . .386$ & \\
Pretest kelompok eksperimen 2 & 0.179 & \\
Pretest kelompok kontrol & 0.631 & Sig.(2-tailed) $>0.05$ \\
Posttest kelompok eksperimen 1 & 0.333 & = Normal \\
Posttest kelompok eksperimen 2 & 0.308 & \\
Posttest kelompok kontrol & 0.856 & \\
\hline
\end{tabular}

Hasil uji normalitas pretest kelompok eksperimen 1 menunjukkan $\mathrm{p}=0,386$ sehingga $\mathrm{p}>0,05$. Uji normalitas pr-test kelompok eksperimen 2 menunjukkan $\mathrm{p}=0,179$ sehingga $\mathrm{p}>0,05$. Uji normalitas pretest kelompok kontrol menunjukkan $\mathrm{p}=0,631$ sehingga $\mathrm{p}>0,05$. Uji normalitas posttest kelompok eksperimen 1 menunjukkan $\mathrm{p}=0,631$ sehingga $\mathrm{p}>0,05$. Uji normalitas posttest kelompok eksperimen 2 menunjukkan $\mathrm{p}=0,308$ sehingga $\mathrm{p}>0,05$. Selanjutnya, uji normalitas posttest kelompok kontrol menunjukkan nilai $\mathrm{p}=0,856$ sehingga $\mathrm{p}>0,05$. Dengan demikian, hipotesis alternatif (Ha) diterima dan hiptesis nol (Ho) ditolak sehingga data berdistribusi normal.

\section{Uji Homogenitas}

Uji homogenitas dilakukan dengan uji lavene statistic. Kriteria pengujian yang digunakan untuk menentukan homogenitas populasi dalam penelitian ini adalah Ho ditolak apabila nilai Significancy ( $p$-value)>dari nilai alpha yang ditetapkan sehingga varian variabel homogen. Sebaliknya, Ho diterima apabila nilai Significancy $(p$-value $)<$ dari nilai alpha yang ditetapkan sehingga varian variabel tidak homogen. Hasil uji homogenitas posttest pada kelompok eksperimen dan kelompok kontrol ditunjukkan dalam Tabel 3.

Tabel 3. Ringkasan Hasil Uji Homogenitas 


\begin{tabular}{ccc}
\hline Variable & Sig. & Keterangan \\
\hline Penilaian pretest menulis deskripsi & 0.952 & \\
Penilaian posttest menulis deskripsi & 0.238 & Sig. $>0.05=$ homogeny \\
\hline
\end{tabular}

Dari hasil ringkasan hasil uji homogenitas di atas diperoleh nilai sig. (p) pretest menulis deskripsi kelompok eksperimen 1, eksperimen 2, dan kontrol sebesar 0,952. Selanjutnya, diperoleh nilai sig. (p) posttest menulis deskripsi kelompok eksperimen 1, eksperimen 2, dan kontrol sebesar 0,238. Oleh karena itu, ringkasan hasil uji homogenitas tersebut memiliki nilai $\mathrm{p}>0,05$ yang berarti Ho yang dinyatakan bahwa data penelitian bervarian heterogen ditolak. Oleh karena itu, dapat disimpulkan bahwa pada taraf signifikansi 5\%, semua kelompok yang digunakan dalam penelitian ini mempunyai variansi kelompok yang homogen atau ketiga kelompok bervarian sama.

\section{Hasil Uji Hipotesis}

Pengujian asumsi normalitas sebaran dan homogenitas varian telah terpenuhi. Hal ini berarti persyaratan parametrik uji hipotesis menggunakan Anava terpenuhi. Dalam penelitian ini, uji perbedaan menulis deskripsi antara kelompok kontrol dan kelompok eksperimen baik menulis deskripsi hasil pretes maupun postest menggunakan Anava satu jalur.

\section{Uji Hipotesis Pertama}

Hipotesis pertama penelitian ini adalah ada perbedaan yang signifikan antara model kooperatif tipe picture and picture, tipe think-pair-share, dan model konvensional dalam pembelajaran menulis deskripsi peserta didik kelas X SMAK Frateran Ndao Ende. Berdasarkan hasil uji Anava posttest dapat disimpulkan bahwa terdapat perbedaan antara model kooperatif tipe picture and picture, tipe think-pairshare, dan model konvensional yang signifikan dalam pembelajaran menulis deskripsi peserta didik kelas X SMAK Frateran Ndao Ende. Hasil perhitungan dengan program SPSS versi 20, diperoleh ringkasan uji Anava untuk melihat tingkat perbedaan antara model pembelajaran pada kelompok eksperimen dan kelompok kontrol, yaitu model pembelajaran kooperatif tipe picture and picture, tipe think-pair- 
share, dan model konvensional dalam pembelajaran menulis deskripsi yang disajikan pada Tabel 4 di bawah ini.

Tabel 4. Hasil Uji Anava Postest

\begin{tabular}{|c|c|c|c|c|c|}
\hline & Sum of Squares & & & & \\
\hline Between Groups & 7080.067 & 2 & 3540.033 & 140.578 & .000 \\
\hline Within Groups & 2190.833 & 87 & 25.182 & & \\
\hline Total & 9270.900 & 89 & & & \\
\hline
\end{tabular}

Berdasarkan hasil uji Anava di atas, diperoleh nilai $\mathrm{F}$ sebesar 140,578 dan signifikansi $(\mathrm{p})<0,05$. Jadi, dapat disimpulkan bahwa terdapat perbedaan yang signifikan antara model kooperatif tipe picture and picture, tipe think-pair-share, dan model konvensional dalam pembelajaran menulis deskripsi peserta didik kelas $\mathrm{X}$ SMAK Frateran Ndao Ende.

\section{Uji Hipotesis Kedua}

Hipotesis kedua dalam penelitian ini adalah urutan keefektifan model kooperatif tipe picture and picture, tipe think-pair-share, dan model konvensional yang signifikan dalam pembelajaran menulis deskripsi peserta didik kelas X SMAK Frateran Ndao Ende. Pengujian hipotesis kedua ini menggunakan uji Scheffe dengan menggunakan program SPSS versi 20 dan diperoleh ringkasan uji Scheffe untuk melihat tingkat keefektifan model pembelajaran pada kelompok eksperimen dan kelompok kontrol, yaitu model pembelajaran kooperatif tipe picture and picture, tipe think-pair-share, dan model konvensional dalam pembelajaran menulis deskripsi disajikan pada Tabel 5.

Tabel 5. Hasil Uji Scheffe Model Kooperatif Tipe picture and picture, Think-Pair-Share, dan Konvensional Multiple Comparisons

\begin{tabular}{|c|c|c|c|c|c|c|}
\hline \multirow[b]{2}{*}{ (I) Model } & \multirow[b]{2}{*}{ (J) Model } & \multirow{2}{*}{$\begin{array}{c}\text { Mean Difference } \\
\text { (I-J) }\end{array}$} & \multirow{2}{*}{$\begin{array}{l}\text { Std. } \\
\text { Error }\end{array}$} & \multirow[t]{2}{*}{ Sig. } & \multicolumn{2}{|c|}{ 95\% Confidence Interval } \\
\hline & & & & & Lower Bound & Upper Bound \\
\hline \multirow[t]{2}{*}{ Eksperimen1 } & Eksperimen2 & $-3.633^{*}$ & 1.296 & .023 & -6.86 & -.41 \\
\hline & Kontrol & $16.733^{*}$ & 1.296 & .000 & 13.51 & 19.96 \\
\hline \multirow[t]{2}{*}{ Eksperimen2 } & Eksperimen 1 & $3.633^{*}$ & 1.296 & .23 & 41 & 6.86 \\
\hline & Kontrol & $20.367^{*}$ & 1.296 & .000 & 17.14 & 23.59 \\
\hline \multirow[t]{2}{*}{ Kontrol } & Eksperimen 1 & $-16.733^{*}$ & 1.296 & .000 & -19.96 & -13.51 \\
\hline & Eksperimen2 & $-20.367^{*}$ & 1.296 & .000 & -23.59 & -17.14 \\
\hline
\end{tabular}


Berdasarkan ringkasan hasil uji Scheffe di atas diketahui bahwa antara penggunaan model kooperatif tipe picture and picture dan tipe think-pair-share dalam pembelajaran menulis deskripsi peserta didik kelas X SMAK Frateran Ndao Ende, diperoleh probabilitas sebesar 0,023 lebih kecil dari taraf signifikansi yang ditetapkan, yaitu 0,05 (5\%), maka Ho ditolak dan Ha diterima. Kesimpulan pengujian hipotesis tersebut adalah terdapat perbedaan keefektifan antara model tersebut dan nilai mean difference sebesar 3,633 yang artinya penggunaan model kooperatif tipe think-pairshare lebih efektif dibandingkan model kooperatif tipe picture and picture dalam pembelajaran menulis deskripsi. Hasil perhitungan dengan uji Scheffe tentang keefektifan antara penggunaan model kooperatif tipe picture and picture dan model konvensional dalam pembelajaran menulis deksripsi diperoleh probabilitas (p) sebesar 0,000 yang lebih kecil dari taraf signifikansi yang ditetapkan, yaitu 0,05 (5\%), maka terdapat perbedaan keefektifan, artinya terdapat perbedaan keefektifan antara penggunaan model kooperatif tipe picture and picture dan model konvensional dalam pembelajaran menulis deksripsi. Selanjutnya, nilai mean difference sebesar 16,733 yang artinya model kooperatif tipe picture and picture lebih efektif dibandingkan model konvensional. Secara keseluruhan hasil perhitungan dengan uji Scheffe tentang keefektifan antara penggunaan model kooperatif tipe think-pair-share dan model konvensional dalam pembelajaran menulis dekripsi diperoleh probabilitas (p) sebesar 0,000 lebih kecil dari taraf signifikansi yang ditetapkan, yaitu 0,05 (5\%). Jadi, ada perbedaan yang signifikan antara model kooperatif tipe think-pair-share dan model konvensional dalam pembelajaran menulis deksripsi dengan nilai mean difference antara kedua model pembelajaran tersebut sebesar 20,367. Oleh karena itu, dapat disimpulkan bahwa model pembelajaran kooperatif tipe think-pair-share lebih efektif dibandingkan model konvensional.

Jadi, secara keseluruhan hasil yang diperoleh melalui uji Scheffe adalah penggunaan model kooperatif tipe think-pair-share dalam pembelajaran menulis 
deksripsi merupakan model pembelajaran yang paling efektif, diikuti oleh model kooperatif tipe picture and picture, dan yang terakhir adalah model konvensional.

\section{Pembahasan Hasil Penelitian}

Pada bagian ini dikemukakan pembahasan terhadap hasil-hasil penelitian yang meliputi (1) ada perbedaan yang signifikan antara model kooperatif tipe picture and picture, tipe think-pair-share, dan model konvensional dalam pembelajaran menulis deskripsi peserta didik kelas X SMAK Frateran Ndao Ende dan (2) ada keefektifan model kooperatif tipe picture and picture, tipe think-pair-share, dan model konvensional dalam pembelajaran menulis deskripsi peserta didik kelas X SMAK Frateran Ndao Ende.

Ada Perbedaan yang Signifikan antara Model Kooperatif Tipe Picture and Picture, Tipe Think-Pair-Share, dan Model Konvensional dalam Pembelajaran Menulis Deskripsi Peserta Didik Kelas X SMAK Frateran Ndao Ende

Secara keseluruhan dari perhitungan Anava tentang penerapan model pembelajaran kooperatif antara model kooperatif tipe picture and picture, tipe thinkpair-share, dan model konvensional dalam pembelajaran menulis deskripsi peserta didik kelas X SMAK Frateran Ndao Ende menghasilkan signifikansi (p) < dari taraf signifikansi yang ditentukan, yaitu $0,05 \quad(\mathrm{p}=0,000<0,05)$. Kesimpulannya adalah terdapat perbedaan antara penerapan model kooperatif tipe picture and picture, thinkpair-share, dan konvensional dalam pembelajaran menulis deskripsi peserta didik kelas X SMAK Frateran Ndao Ende.

Ada Keefektifan Model Kooperatif Tipe Picture and Picture, Tipe Think-Pair-Share, dan Model Konvensional dalam Pembelajaran Menulis Deskripsi Peserta Didik Kelas X SMAK Frateran Ndao Ende

Berdasarkan hasil uji Scheffe tentang keefektifan antara penerapan model kooperatif tipe picture and picture dan think-pair-share diperoleh signifikansi $(\mathrm{p})=0,023<0,05$. Hasil uji Scheffe tentang keefektifan antara penerapan model kooperatif tipe picture and picture dan model konvensional diperoleh signifikansi, $\mathrm{p}<0,05$, sedangkan hasil uji Scheffe tentang keefektifan antara penerapan model 
kooperatif tipe think-pair-share dan model konvensional diperoleh signifikansi, $\mathrm{p}<$ 0,05. Jadi, dapat disimpulkan bahwa model kooperatif tipe think-pair-share paling efektif daripada model kooperatif tipe picture and picture dan konvensional dalam pembelajaran menulis deskripsi peserta didik kelas X SMAK Frateran Ndao Ende.

Adapun urutan model pembelajaran kooperatif yang paling efektif dalam pembelajaran menulis deskripsi adalah (a) model pembelajaran kooperatif tipe thinkpair-share, (b) tipe picture and picture, dan model konvensional. Model kooperatif tipe think-pair-share membantu peserta didik dalam mencari dan mengorganisir topik-topik yang akan dikembangkan menjadi sebuah karangan. Dalam kemampuan menulis, penggunaan model ini akan membantu peserta didik dalam mengorganisir ide-ide yang akan ditulisnya sehingga hasil tulisan peserta didik memiliki kohesi dan koherensi yang baik. Dalam uji coba penelitian ini, model kooperatif tipe think-pairshare merupakan model pembelajaran yang paling efektif dibandingkan dengan model kooperatif tipe picture and picture. Sebagaimana yang dikatakan oleh Arends (2008:15), think-pair-share adalah suatu model yang menantang asumsi bahwa semua resitasi atau diskusi perlu dilakukan dalam setting seluruh kelompok dan memiliki prosedur-prosedur built-in untuk memberikan lebih banyak waktu kepada peserta didik untuk berpikir, merespons, dan saling membantu. Berpikir (think), berdiskusi (pair), dan berbagi (share) dapat dijadikan sebagai acuan bagi peserta didik dalam mengembangkan karangan yang akan ditulis. Model ini akan membantu peserta didik memvisualisasikan ide-ide secara konkret. Penggambaran secara konkret terhadap ide-ide dimiliki oleh peserta didik akan lebih mudah dikembangkan dalam menulis daripada ide-ide abstrak yang terdapat dalam pikiran mereka. Cara ini efektif menuntun peserta didik dalam menulis karangan sehingga hasil karangan peserta didik dilihat dari segi isi dan organisasi karangan menjadi semakin luas, mendalam, serta memiliki kepaduan yang baik antarparagraf. Dengan memperhatikan beberapa hal tersebut, dapat dikatakan bahwa penggunaan model kooperatif tipe picture and picture dan tipe thinkpair-share membantu tercapainya hasil pembelajaran yang diinginkan dalam menulis deskripsi. 


\section{DAFTAR PUSTAKA}

Arends, Richard. (2008). Learning to Teach. (Edisi Tujuh). Yogyakarta: Pustaka Pelajar

ARSLAN, R. S. (2014). Integrating Feedback into Prospective English Language Teachers' Writing Process via Blogs and Portfolios. TOJET: The Turkish Online Journal of Educational Technology, 13, 131-150.

Abidin, Y. (2014). Desain Sistem Pembelajaran dalam Konteks Kurikulum 2013. Bandung: Refika Aditama.

Dalman, H. (2014). Keterampilan Menulis. Jakarta: PT Raja Grafindo Persada.

Hartoto, T. (2016). Model Pembelajaran Kooperatif Tipe Group Investigation (GI) Meningkatkan Aktivitas dan Hasil Belajar Sejarah. Jurnal Historia, 4, 131141.

Jacobsen, D. A.; Eggen, P.; Kauchak, D. (2009). Metode-Metode Pengajaran. Penerbit: Pustaka Pelajar.

Junus, A. M. (2002). Keterampilan Menulis. Makassar: Badan Penerbit UNM

Keraf, G. (1981). Eksposisi dan Deskripsi. Jakarta: Nusa Indah.

Nurhadi. (2003). Pembelajaran Kontekstual (Cooperative Learning di Ruang-Ruang Kelas, Jakarta: Gramedia

Rofie uddin, A., dkk. (2001). Pendidikan Bahasa dan Sastra Indonesia di Kelas Tinggi. Malang: Universitas Negeri Malang

Saddhono, K. \& Slamet. (2014). Pembelajaran Keterampilan Bahasa Indonesia Teori dan Aplikasi Edisi 2. Yogyakarta: Graha Ilmu.

Slavin, R.E. (2010). Cooperative Learning, Theory, Research, and Practice. (Terjemahan Narulita Yusron). London: Allymand Bacon. (Buku asli diterbitkan tahun 2005).

Tompkins, G.E. (1994). Teaching Writing: Balancing Process and Product. New York: Macmillan. 